\title{
КОНСТИТУЦИОННО-ПРАВОВЫЕ ОСНОВЫ ВЗАИМОСВЯЗИ ПРАВОВОЙ СИСТЕМЫ АЗЕРБАЙДЖАНСКОЙ РЕСПУБЛИКИ С МЕЖДУНАРОДНЫМ ПРАВОМ
}

\section{CONSTITUTIONAL AND LEGAL \\ FOUNDATIONS OF THE RELATIONSHIP \\ BETWEEN THE LEGAL SYSTEM \\ OF THE REPUBLIC OF AZERBAIJAN \\ AND INTERNATIONAL LAW \\ Rzayev Orkhan Vali oglu}

Summary: The article deals with the constitutional and legal foundations of the relationship between the legal system of the Republic of Azerbaijan and international law. Here, along with the Constitution, acts adopted by the referendum and constitutional laws are analyzed as the legal basis. The article analyzes the static and dynamic aspects of the abovementioned relationship.

Keywords: legal system, norms of international law, norms of national law, international treaty, legislation, Constitution.
$\mathrm{B}$ заимосвязь национальных правовых систем с международным правом включает в себя сложный процесс, который объединяет взаимосвязанные элементы. Этот процесс характеризуется, с одной стороны, правовым своеобразием, сформированным под влиянием социально-экономических, национальных и исторических традиций общества, а с другой стороны, необходимостью на международном уровне правовой интеграции, обусловленной влиянием факторов глобализации и гуманизации международных отношений. Отмеченный процесс попробуем проанализировать на примере национальной правовой системы Азербайджанской Республики (AP).

Поскольку международное право, являющееся продуктом коллективной воли государств, не предусматривает единого «рецепта» для определения его связи с национальными правовыми системами, то возникает неизбежность различия, вытекающего из специфики своеобразия национальных правовых систем по отношению к этому вопросу. Естественно, эта особенность характерна и для взаимосвязи правовой системы АР с международным правом. Прежде чем приступить к анализу этой связи, необходимо обратить внимание на следующие, весьма важные для этого анализа вопросы.

Во-первых, в вопросах взаимосвязи одним из моментов, которые могут быть общими для законодательной
Рзаев Орхан Вели оглу

Аспирант, Северо-Кавказский федеральный университет

r_orxan@mail.ru

Аннотация: В статье говорится о конституционно-правовых основах взаимосвязи правовой системы Азербайджанской Республики (АР) с международным правом. Здесь, наряду с Конституцией, в качестве правовой основы анализируются акты принятые референдумом и конституционные законы. В статье анализируются статические и динамические аспекты вышеуказанной взаимосвязи.

Ключевые слова: правовая система, нормы международного права, нормы национального права, международный договор, законодательство, конституция.

практики и доктрины государств, является разрешение вопроса взаимосвязи в рамках конституции (основного закона) государства. Это связано с тем, что Конституция, устанавливает основные вопросы организации общества, в том числе основы нормотворчества государства, и в тоже время закрепляет особенности участия государства в международных отношениях и взаимоотношения национального законодательства с системой международного права. В современной АР указанные вопросы регулируются принятой всенародным голосованием Конституцией от 12 ноября 1995-го года [14] (далее - Конституция). Эта Конституция скроена на основе принципа уважения норм международного права $[2,294]$. Кстати, в Конституции закреплено множество положений (ст. 7, 10, 12, 148, 151 и др.), относительно взаимосвязи международного права с национальным законодательством. На основании анализа этих норм можно сделать вывод о том, что в Азербайджане создана адекватная и образцовая конституционная основа для внутригосударственного осуществления международных правовых обязательств, принятых на себя нашим государством [4, 17]. С этой точки зрения, неправильным было бы принятие мнения о том, что «трудно установить взаимосвязь между международным правом и внутренним правом, ссылаясь только на конституционные нормы» [3, 535536]. Конечно, явление Конституции основным законом, обусловлено нахождением её в основе законодательной системы AP и обладанием высшей юридической 
силы в АР (Конституция, статья 147). Разумеется, другие нормативные правовые акты, принятые в АР, не вступая в противоречие с Конституцией служат реализации ее положений. Однако, когда речь идет о конституционных основах взаимосвязи национальной правовой системы с международным правом, в эти основы необходимо также включить акты референдума и конституционные законы. Потому что, эти не имеющие одинаковой юридической силы два нормативных акта, будучи принятыми особым образом в отличие от других, являются неотъемлемой частью Конституции $[9,169]$. Так, согласно Конституции, изменения в ее тексте принимаются только путем референдума (статья 152), а дополнения принимаются в форме конституционных законов (статья 156). В отличие от изменений, будем проводить анализ дополнений с точки зрения невключения их в текст Конституции, беря за основу конституционные законы, в частности, конституционный Закон «О нормативных правовых актах» от 21 декабря 2010-го года (№ 21-IVKQ) [17] (далее - Закон от 2010-го года), на который дается ссылка в Конституции (ст.149.VIII).

Во-вторых, с точки зрения правильного восприятия позиции законодательства, необходимо выяснить юридическое содержание понятия «правовая система». Для этого в первую очередь следует отметить, что понятия «система права», «система законодательства» и «правовая система», вовсе не являются синонимами, по своему содержанию это различные понятия. Система права представляет собой внутреннее логическое построение, основанное на координации и взаимосвязях структурных элементов права [9, 222]. Система законодательства представляет собой совокупность нормативных правовых актов, изданных компетентными государственными органами в различных областях государственного управления [9, 241]. А правовая система, сочетанием их обеих, охватывает систему, обладающую более широким содержанием. По мнению С.С. Алексеева, в правовую систему входят основные элементы, имеющие конституционное значение и находящиеся во взаимосвязи: собственно, само право, правовая идеология, правовая практика - состоящая из правоприменения и правотворчества, в том числе система нормативных актов, являющаяся итогом законотворчества [1, 87-88]. Согласно мнению профессора М.Ф. Меликовой, правовая система включает в себя всё разнообразие юридических событий, связанных с правом в той или иной степени: законодательство, систему права, правовые учреждения, формы правовой деятельности государственных органов, учреждений, неправительственных организаций, юридическую практику, правовые идеи, правовую культуру, выступая при этом как цельный комплекс юридических событий. Указанные элементы делятся на три взаимосвязанные группы: 1) законодательство; 2) юридическая практика; 3) правовая идеология [9, 223]. Как усматривается, М.Ф. Меликова отмечая законодатель- ство в качестве системного элемента, тем самым идентифицирует его с системой права, что может породить определенные споры. Конечно же, эти понятия между собой имеют тесную взаимосвязь. Хотя система права носит объективный характер и выражает содержание, определяемое состоянием общественных отношений, в свою очередь, система законодательства в большем объеме отражением субъективных факторов, выступает в качестве формы внешнего выражения правовой нормы [9, 242]. Наряду с этим, система законодательства по объему сферы действия обширнее, чем система права, поскольку охватывает больше областей $[9,244]$.

B-mpemьих, необходимо выяснить содержание процесса взаимосвязи правовой системы АР с международным правом. Следует отметить, что пролцесс обладает двумя обладающими статическим и динамическим характером особенностями. Взаимное соотношение международного права с национальной правовой системой, образует статическую сторону процесса, а национальная правовая имплементация норм международного права, образует динамичную сторону процесса. С точки зрения нашего анализа, как правило динамическая сторона процесса обладает большим значением, в сравнении с носящей доктринальный характер статической стороной. Наряду с этим, необходимо обратить внимание на оба аспекта процесса. Так, независимо от того, насколько это носит доктринальный характер, при определении соотношения норм международного права и норм национального права в рамках национальной правовой системы, мы также должны дать разъяснение по вопросу носящем доктринальный характер.

В юридической литературе отмечается существование дуалистических и монистических теорий касательно взаимного соотношения международного права с национальным правом [6, 570-582]. Согласно теории дуализма в современный период, международное и национальное право представляют собой две разные правовые системы равного значения, которые не подчинены друг другу, и между которыми существует постоянная взаимосвязь $[8,157]$. Монистическая теория, выступающая с позиции единства системы права, принимает международное и национальное право, как составные части единой системы права. Сторонники этой теории разделяются также на две группы: 1) те, кто принимает приоритет национального права; 2) те, кто принимает приоритет международного права [10, 11]. Кроме того, в юридической литературе отмечается существование теории координации касательно вопроса взаимного соотношения. Суть этой теории, нацеленной на устранение негативных сторон двух других теорий, заключается в том, что взаимодействующие международные и национальные правовые системы не противоречат друг другу $[2,271]$. На самом деле, признание любой из этих теорий является политико-правовым вопросом [3, 534]. По мне- 
нию А.Г. Мамедова, соотношение международного права и национального права следует изучать с двух аспектов: политико-правового и исключительно правового. В первом случае, это соотношение следует оценивать как противостояние государственного суверенитета и общечеловеческих интересов. По отношению к этому вопросу, государство выступая с позиции наличия параллельно действующих, равноправных систем права международного и национального права, не признавая приоритета международного права, нейтрализует его влияние на свои внутренние полномочия [7, 30]. Кстати, в доктрине международного права Азербайджана встречается позиция, которая официаль ᄀно признает принятие дуалистической концепции $[2,293 ; 6,581]$. Однако в юридической литературе существуют и противоположные этому позиции. Выступая с позиции признания теории монизма конституциями многих стран, 3.А. Аскеров отмечает, что современная эпоха, является периодом, когда теория монизма вытесняет теорию дуализма. Так, с течением времени перенос центра внимания на права и свободы человека в международном праве и принятие в этом отношении многих оптимальных процессуальных норм, привело к стандартизации норм в области прав человека в международном праве, и это способствовало распространению теории монизма [3, 534]. Этому подходу придается поддержка и в доктрине международного права $[12,29]$. Если давать оценку вопросу взаимного соотношения с чисто юридической точки зрения, то международное и национальное право, обладая сходными и различающимися особенностями, составляют элементы единой системы регулирования - права $[7,30]$.

В последние времена в правовой доктрине Азербайджана, наблюдается формирование нового подхода к взаимосвязи международного права с нациолнальным законодательством. Суть этого подхода, который признает правовую систему АР в качестве правового порядка, «дружественного международному праву», заключается в том чтобы, не затрагивая вопросы взаимного соотношения при установлении взаимосвязи, необходимо направить основное внимание на реализацию норм международного права в национальную правовую систему [5, 58-73].

Сочетание правовой системы АР с нормами международного права, возможно, только путем признания приоритета норм международного права по отношению к национальному праву $[13,59]$. Приоритет международного права означает, установление внутреннего законодательства государства в соответствии с международными договорами и общепризнанными принципами международного права. Признание этого приоритета обуславливает наличие того, что с точки зрения международного права, государство является правовым государством [7, 103]. Главенствующей идеей правового государства является признание приоритета права во всех сферах общественной жизни и деятельности государства [11, 378]. Как указано в части I статьи 7-й Конституции, Азербайджанское государство является демократической, праволвой, светской, унитарной республикой. Согласно части II этой статьи, государственная власть ограничивается во внутренних вопросах только правом, а во внешних вопросах - только положениями, вытекающими из международных договоров, стороной которых является АР. Закон от 2010-го года определяет приоритет общепризᄀнанных принципов и норм международного права, как основной принцип нормотворческой деятельности в АР (ст. 8.0.3). Сообразно этому принципу, AP признает приоритет общепризнанных принципов и норм международного права, и обеспечивает приведение законодательства АР к их соответствию (ст. 22). Считаем, что приведение к соответствию национального законодательства с нормами международного права, образует материально-правовой аспект приоритета международного права, а в процессуально-правовом смысле, в процессе применения выражается в передаче приоритета нормам международного права. Так, в преамбуле Конституционного Закона от 12 мая 2006-го года (№ 106-IIIKQ) «Об обратной силе применения закона, устанавливающего ответственность за международные преступления» [16], отмечается, что применение действующих норм уголовного законодательства предусматривающих ответственность в АР за преступления против мира и человечества, геноцид и войну, проводится с целью приведения их в соответствие с соответствующими положениями Конвенции «О защите прав человека и основных свобод» и Международного пакта «О гражданских и политических правах». Схожее положение предусмотрено в Конституционном законе от 24 декабря 2002-го года (№ 404-ІІКQ) «О регулировании осуществления прав и свобод человека в АР» [15]. Целью принятия этого Закона, является приведение осуществления прав и свобод человека в АР в соответствие с Конвенцией «О защите прав человека и основных свобод». Положения отмечаемых последних законов, выступают в качестве реализации - положения, закрепленного в статье 12.ІІ Конституции: «Права и свободы человека и гражданина, перечисленные в Конституции, применяются в соответствии с международными договорами, стороной которых является АР» и статей 8 и 22 Закона от 2010-го года, и имеют особый характер в отношении этих положений. Как усматривается, законодательство АР в этом случае, как правило отдает приоритет нормам международных договоров. Например, положения статьи 12.ІІ Конституции или статьи 151-й гласящей: «При возникновении противоречия между нормативными правовыми актами, входящими в систему законодательства АР (исключая Конституцию АР и принятые путем референдума акты), и межгосударственными договорами, участницей которых является AР, применяются международные договоры» и т.п. положения, следует в качестве приоритета воспринимать в процессуально-правовом смысле. 


\section{ЛИТЕРАТУРА}

1. Алексеев С.С. Общая теория права. Т.1. М.1981

2. Алиев А.И. Международно-правовое регулирование статуса иностранцев и лиц без гражданства: теория и практика. Баку, Ширваннешр, 2007 (на азерб. языке)

3. Аскеров 3.А. Конституционное право. Учебник. Баку, Изд. Бакинский Университет, 2011 (на азерб. языке)

4. Гусейнов Л.Г. Конституция Азербайджанской Республики, права человека и международное право // Beynəlxalq hüquq jurnall, 1998, № 1

5. Гусейнов Т.И. Экологическая безопасность Азербайджанской Республики: международно-правовые и внутригосударственные аспекты / Диссертация док. юрид. наук. Баку. 2018

6. Курс международное (публичное) право. Учебник. Том І. Общая часть. Баку, 2018 (на азерб. языке)

7. Мамедов А.Г. Законодательство Азербайджанской Республики о международном частном праве и международное право // Диссертация на соискание ученой степени кандидата юридических наук. Баку, 2005 (на азерб. языке)

8. Международное публичное право. Учебник / от. ред. К.А. Бекяшев. М., 2009

9. Меликова М.Ф. Теория права. Учебник. 3-е изд. перераб. и доп.. Баку, Наука и образования, 2019 (на азерб. языке)

10. Мюллерсон Р.А. Соотношение международного и национального права. М., 1982

11. Общая теория права и государства. Учебник / Под ред. В.В. Лазарева. 2-е изд. перераб. и доп. М, 1996

12. Садыгов А.И. Международные нефтяные контракты АР в системе международного энергетического права / Диссертация кан. юрид. наук. Баку. 2003

13. Сулейманлы С.А. Проблемы международно-правовые регулирование охраны культурного наследия и законодательство Азербайджанской Республики. Баку, Изд. Азербайджан, 2018 (на азерб. языке)

(c) Рзаев Орхан Вели оглу (r_orxan@mail.ru).

Журнал «Современная наука: актуальные проблемы теории и практики»

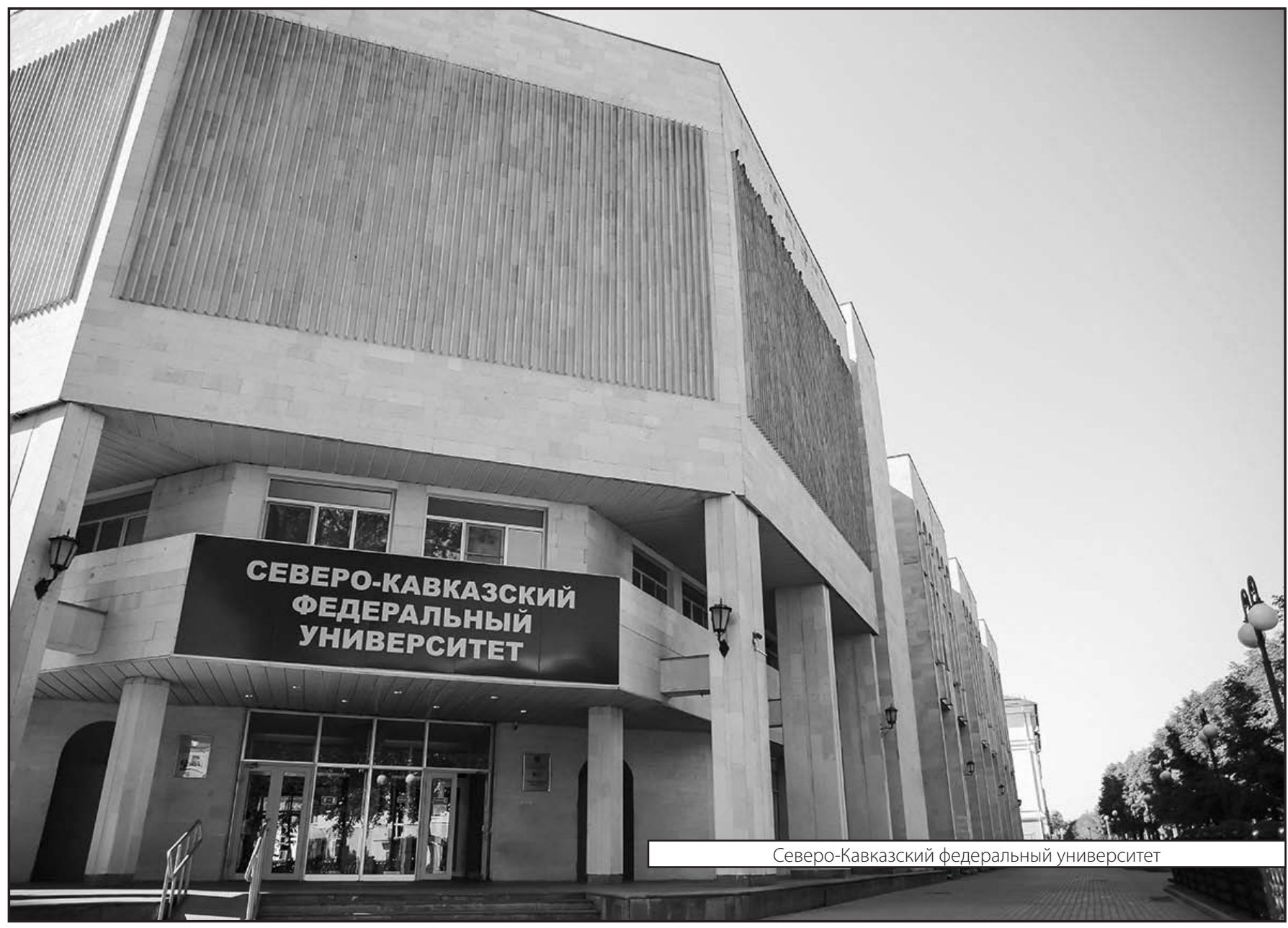

